\title{
Danijel Vojak
}

(Institut društvenih znanosti Ivo Pilar, Zagreb)

\section{STRADANJE ROMA U SLAVONIJI ZA VRIJEME DRUGOG SVJETSKOG RATA, 1941. - 1945.}

UDK 355.1-058.6(497.5 Slavonija)“1941/1945“

$341.48(497.5=214.58)$ “1941/1945“"

Prethodno priopćenje

Primljeno: 13. 4. 2019.

\begin{abstract}
U radu je analiziran položaj romskog stanovništva na slavonskom području za vrijeme Drugoga svjetskog rata. Istraživanje je bilo usmjereno na analizu politike državnih i lokalnih vlasti prema Romima, koja je uključivala mjere poput njihovog popisivanja, zabrane kretanja i u konačnici njihove sustavne deportacije u jasenovački logor, gdje je znatan dio njih ubijen. Drugi dio odnosi se na analizu odnosa neromskog stanovništva na slavonskom području prema progonu i stradanju njihovih romskih sumještana, unutar kojeg su opisani slučajevi u kojima je dio Slavonaca izravno nastojao spasiti Rome molbama i drugim intervencijama kod ustaških lokalnih i državnih vlasti.

Ključne riječi: Romi, Slavonija, Nezavisna Država Hrvatska, Drugi svjetski rat, stradanje
\end{abstract}

\section{Uvod}

Romsko stanovništvo danas živi na slavonskim područjima više od pet stoljeća i time čini jednu od najstarijih manjinskih skupina. Njihov suživot sa stanovništvom Slavonije bio je sličan s onim na ostalim hrvatskim područjima, koji je bio većinom obilježen razdobljima represivne asimilacijske politike državnih i lokalnih vlasti prema Romima. Vrhunac takve politike, koja se može obuhvatiti pojmom anticiganizam, dogodio se za vrijeme Drugoga svjetskog rata, kada je znatan dio romskog stanovništva na slavonskom području stradao kao posljedica rasne politike ustaških vlasti. Izostanak znanstvenih istraživanja stradanja Roma u Slavoniji za vrijeme Drugoga svjetskog rata jedan je od poticaja za istraživanje u ovom radu. U ovom radu nastoji se odgovoriti na pitanje nužne usporedbe politike državnih i lokalnih vlasti prema Romima, kao i na pitanja usporedbe tadašnjeg položaja Roma u Slavoniji s ostalim dijelovima Nezavisne Države Hrvatske. 


\section{Izvori, literatura}

Istraživanje je prostorno ograničeno na područja Slavonije koja su za vrijeme NDH bila u sastavu velikih župa: Livac-Zapolje, Posavje, Baranja i Vuka. Analiza je obuhvatila dosad neobjavljene dokumente u državnim arhivama u Osijeku i Slavonskom Brodu (i njegovom odjelu u Požegi), te Hrvatskom državnom arhivu u Zagrebu. Osim toga, obrađena je relevantna periodika u Nacionalnoj i sveučilišnoj knjižnici u Zagrebu. U osječkom arhivu izdvojio bih fond Gradskog poglavarstva Osijek, koji je temeljni fond za proučavanje zbivanja na širem osječkom području za vrijeme NDH. U arhivu u Slavonskom Brodu potrebno je izdvojiti fond Velike župe Posavje, dok je $\mathrm{u}$ njegovom arhivskom odjelu u Požegu analiziran fond Kotarske oblasti u Požegi. Upravo pronalazak relevantnih dokumenta u arhivskim institucijama izvan Zagreba ukazuje na potrebu intenziviranja sustavnijeg proučavanja lokalnih arhiva kako bi se bolje razumio položaj Roma u NDH.

O povijesti Roma na slavonskom području za vrijeme Drugog svjetskog rata nije se sustavno istraživalo. Slavica Hrečkovski se u svom djelu iz 1982. Slavonski Brod u NOB i socijalističkoj revoluciji 1941 - 1945. u nekoliko navoda osvrnula na položaj Roma u Slavonskom Brodu za vrijeme NDH. Ista znanstvenica je 1984. sudjelovala na okruglom stolu u Jasenovcu, gdje je izlagala o progonu i deportaciji slavonskih Roma u jasenovački koncentracijski logor. Njezin rad je objavljen godinu dana kasnije u posebnom zborniku radova. ${ }^{1}$ Narcisa Lengel-Krizman se zatim u radu o Romima u NDH osvrnula i na položaj Roma na slavonskom području. ${ }^{2}$ Ista autorica je 2003. izdala djelo o stradanju Roma u jasenovačkom koncentracijskom logoru, gdje je analizirala i stradanje Roma na slavonskom području. ${ }^{3}$ Navedeni prilozi su ujedno i određeni pokazatelj marginalnosti ove tematike $u$ hrvatskoj historiografiji.

\section{Položaj Roma na slavonskom području uoči Drugoga svjetskog rata}

Kako bi se bolje razumio položaj Roma u Slavoniji u Drugom svjetskom ratu potrebno se ukratko osvrnuti na njihov položaj u prethodnim razdobljima, i to posebice između dva svjetska rata. Prisutnost romskog stanovništva na slavonskom području posebno je zabilježena od XVIII. st., kada ih habsburške vlasti nakon Mira u Sremskim Karlovcima (1699.) naseljavaju i na slavonska

\footnotetext{
${ }^{1}$ Slavica Hrečkovski, „Progoni i deportacije slavonskih Roma u koncentracioni logor Jasenovac“, u: Okrugli stol 21. travnja 1984. Materijali s rasprave, ur. Dobrila Borović (Jasenovac, 1985), 35-38.

${ }^{2}$ Narcisa Lengel-Krizman, „Prilog proučavanju terora u tzv. NDH: Sudbina Roma 1941 1945“, Časopis za suvremenu povijest 18 (1986), 1: 29-42.

${ }^{3}$ Narcisa Lengel-Krizman, Genocid nad Romima. Jasenovac 1942. (Jasenovac - Zagreb: Javna ustanova Spomen-područje Jasenovac; Denona, 2003).
} 
područja. Tada su habsburške vlasti imenovale Mitrofana Popovića, vikara manastira Ćelija, kao „direktora rackih Cigana“, i to sa zadaćom da prisili nomadske Rome između rijeka Drave i Save na sjedilački „uredan i moralan način života“. ${ }^{4}$ Istodobno, od kraja XVII. st. u izvorima se češće spominju Romi, kao što to pokazuju matice vjenčanih i krštenih župe Sv. Roka s virovitičkog područja iz 1695. i 1708. ${ }^{5}$ Od sredine istog stoljeća slavonski Romi bili su pod znatnim asimilacijskim pritiskom za vrijeme vladavine Marije Terezije i Josipa II, koji su donijeli niz odredbi kojima su, između ostalog, propisali njihovo stalno naseljavanje, porezna i druga davanja državi i lokalnim feudalcima, zabranu korištenja njihovog imena, zanimanja i običaja, oduzimanje romske djece i njihovo odgajanje $u$ kršćanskim građanskim i seoskim obiteljima te obrazovanje za obrtnike i vojnike. ${ }^{6}$ Iako su njihove reforme bile neuspješne, ponajviše zbog otpora lokalnih vlasti i nedovoljne podrške državnih vlasti, zakonodavni pritisak vlasti nad Romima na slavonskim područjima nastavio se kroz XIX. st. i prvu polovinu XX. st. ${ }^{7}$

Nameće se pitanje koliko je Roma živjelo na slavonskom području uoči osnivanja NDH. U odgovoru na ovo pitanje mora se imati na umu kako nije moguće utvrditi stvaran broj Roma na slavonskim područjima nakon osnivanja NDH, budući da se 1941. nije proveo popis stanovništva. Stoga se broj Roma na ovom području mora procijeniti na temelju popisa stanovništva iz 1931. Tako je na slavonskom području živjelo između 2364 Roma (1921.) i 5319 Roma (1931.). Ukoliko se usporedi broj Roma na slavonskom području s ostatkom hrvatskih područja, iznosio je između 36,88 \% (1921.) i 33,53\% (1931.), tj. oko jedne trećine od ukupnog broja Roma živjelo je na slavonskom području u međuratnom razdoblju. Najviše su živjeli u đakovačkom, slatinskom i valpovačkom kotaru, a najmanje u zapadnoslavonskim kotarima (Novska, Pakrac i Požega). Osim sumarnih brojčanih podataka, prema popisu stanovništva iz 1931. primjetno je kako je većina Roma živjela na ruralnim područjima, bila mlade dobne strukture i neobrazovana (nepismena) te većinom pravoslavne i rimokatoličke vjeroispovijesti. ${ }^{8}$

${ }^{4}$ Slavko Gavrilović, Srem od kraja XVII. do sredine XVIII veka (Novi Sad, 1979), 51.

${ }^{5}$ Stanovništvo Virovitice $i$ okolnih sela: matica krštenih i vjenčanika župe sv. Roka 1686.1717. = Liber baptizatorum et copulatorum Viroviticzae: ab anno 1686 usque ad 1717., prev. i prir. Stjepan Sršan (Osijek, 2004), 133, 134, 206, 221, 254, 265, 272.

${ }^{6}$ Danijel Vojak, U predvečerje rata: Romi u Hrvatskoj 1918. - 1941. (Zagreb, 2013), 24-25.

${ }^{7}$ Više o povijesti Roma na slavonskim područjima u XIX. i XX. st. vidjeti kod: Danijel Vojak, „Bilješke iz povijesti Roma na području Slavonije, 1850.-1941.“, Scrinia Slavonica: Godišnjak Podružnice za povijest Slavonije, Srijema i Baranje hrvatskog instituta za povijest 5 (2005), 432-461.

${ }^{8}$ Vojak, „Bilješke iz povijesti“, 439-460. 
Tablica 1. Broj Roma na slavonskom području u međuratnom razdoblju, 1921. - 1931.

\begin{tabular}{|l|c|c|l|c|c|}
\hline $\begin{array}{l}\text { Županija } \\
\text { Bjelovarsko-križevačka }\end{array}$ & $\mathbf{1 9 2 1 .}$ & $\mathbf{1 9 3 1 .}$ & $\begin{array}{l}\text { Županija } \\
\text { Virovitička }\end{array}$ & $\mathbf{1 9 2 1 .}$ & $\mathbf{1 9 3 1 .}$ \\
\hline kotar Garešnica & 81 & 401 & kotar Đakovo & 208 & 834 \\
\hline kotar Grubišno polje & 104 & 135 & kotar Donji Miholjac & 221 & 556 \\
\hline SLAVONIJA & $\mathbf{1 8 5}$ & $\mathbf{5 3 6}$ & kotar Našice & 287 & 470 \\
\hline Županija Požeška & & & kotar Slatina & 395 & 804 \\
\hline kotar Brod & 22 & 209 & kotar Valpovo & 329 & 709 \\
\hline kotar Daruvar & 53 & 131 & kotar Virovitica & 247 & 297 \\
\hline kotar Nova Gradiška & 94 & 95 & kotar Osijek & 286 & 444 \\
\hline kotar Novska & 34 & 14 & Grad Virovitica & 3 & 87 \\
\hline kotar Pakrac & & 39 & Grad Osijek & 1 & 7 \\
\hline kotar Požega & & 88 & SLAVONIJA & $\mathbf{1 9 7 7}$ & $\mathbf{4 2 0 8}$ \\
\hline Grad [Slavonski] Brod & & 6 & $\begin{array}{l}\text { Ukupno } \\
\text { SLAVONIJA }\end{array}$ & $\mathbf{2 1 8 0}$ & $\mathbf{4 7 9 0}$ \\
\hline SLAVONIJA & $\mathbf{2 0 3}$ & $\mathbf{5 8 2}$ & Ukupno HRVATSKA & $\mathbf{5 9 1 1}$ & 14.284 \\
\hline
\end{tabular}

Izvori: Hrvatski državni arhiv, Republički zavod za statistiku SRH, sign. HR-HDA-367 (dalje HR-HDA-367), Popis stanovništva 1921., kut. 45, sv. 58; HR-HDA-367, kut. 55, sv. 70.

Nadalje, potrebno je napomenuti kako je na području Slavonije u međuratnom razdoblju živjelo nekoliko romskih skupina, koje su se međusobno razlikovale prema načinu života (nomadski ili sjedilački), vrsti zanimanja (obrada metala ili drveta, sviranje) i jeziku (znanje romskog, rumunjskog, mađarskog ili hrvatskog). U dokumentima i novinama tako su se spominjali Kolompari, Koritari, Drobni kovači i Čergari. ${ }^{9}$

\footnotetext{
${ }^{9}$ Ove romske skupine bile su drugačije nazivane od drugih tadašnjih znanstvenika, poput Franje Fanceva, koji je 1912. u Narodnim novinama opširno pisao o Kolomparima (nomadima koji govore ciganskim jezikom s indijskim narječjem, a bave se popravkom kotlova, trgovinom konja i prošnjom), Koritarima (sjedilačka skupina koja govori rumunjskim jezikom, nose cigansku odjeću, izrađuju korita i kućanske predmete) i Drobnim kovačima (sjedilačka skupina, trgovci konjima i glazbenici, a govore umjetnim - ,gegavačkim“ jezikom). Slično njemu je Viktor Horvat 1942. u Hrvatskoj Enciklopediji razlikovao Turske Cigane (žive na području gornjeg Pokuplja, Baranje i Bačke, govore arhaičnim ciganskim jezikom), Rumunjske Cigane (između njih razlikuje stalno naseljene Cigane u istočnoj Hrvatskoj i Srijemu i čergaše na prostoru od Podunavlja do Podravine; govore poluromaniziranim romskim/ciganskim narječjem) i Karavlase (žive na prostoru gornje Posavine i Like, govore rumunjskim jezikom, no upitno je mogu li ih se smatrati Romima). Danas u Hrvatskoj žive ddvije romske skupine: Bajaše i Rome koji govore indoeuropski jezik «romani chib». Bajaši vuku svoje porijeklo iz Rumunjske i Mađarske, govore „ljimba d bajaš jezikom“ (bajaški dijalekt starorumunjskog jezika), a bavili su se i obrađivanjem drva (npr. koritarstvom). U drugoj skupini Roma pripadaju druga plemena, npr. Kanjari, Kaloperi, Haškalije, Kalderaši..., a oni se bave trgovinom, obradom metala i glazbom. Iz navedenog se može zaključiti
} 
Također, potrebno se osvrnuti na odnos slavonskog stanovništva prema Romima u razdoblju uoči Drugoga svjetskog rata. Postojeća istraživanja ukazuju kako je neromsko stanovništvo u Slavoniji većinom negativno percipiralo Rome kao besposličare i lijenčine, varalice i kradljivice, otimače djece i sl. Takva je negativna percepcija, temeljena na višestoljetnim predrasudama o Romima kao vječnim drugima, bila prisutna i kod institucija vlasti. U tom kontekstu uočljivi su u primjerima odgovora općinskih vlasti Savske banovine na anketu o potrebi kolonizacije Roma, koju je 1937. i 1938. provodio Agrarno-pravni odjel navedene banovine. ${ }^{10}$ Nerazumijevanje između romskog $\mathrm{i}$ neromskog stanovništva često je dovodilo i do nasilnih sukoba, u kojima su Romi bili istjerani, a njihova imovina oduzeta ili spaljena. ${ }^{11}$

Poznati su slučajevi nasilja seoskog stanovništva nad Romima krajem 1939. i na slavonskim područjima u Banovini Hrvatskoj, a među njima najpoznatiji je bio slučaj u Velikoj Kopanici (u kotaru Slavonski Brod), kada je 400-tinjak seljaka iz tog sela sredinom veljače 1941. protjeralo Rome, porušivši im više kuća. Povod za nasilje bilo je navodno skrivanje trojice Roma u Velikoj Kopanici, osumnjičenih za krađe raznih predmeta tamošnjim seljacima. O ovom događaju su izvještavale neke novine, ističući kako se dogodio „,narodni sud“ i „strašna osveta“ seljaka, te kako su nasilni postupci seljaka shvatljivi jer im je „dozlogrdio“ nered i pljačke. Najveću pažnju tom događaju posvetio je zagrebački list Novosti, navodeći kako su u Velikoj Kopanici Romi živjeli već pedeset godina, mirno se baveći „,poštenim životom“ i prosjačenjem. No, međusobni odnosi između seoskog i romskog stanovništva promijenili su se nakon provedene komasacije u ovom selu, koja je dovela do osiromašenja seljaka i time smanjila mogućnost njihove "darežljivosti“" prema Romima. Zbog toga su se Romi okrenuli krađama i trovanju stoke kao jedinom načinu preživljavanja. Središnje banske vlasti su reagirale tek u ožujku 1941., kada su u dopisu slavonskobrodskoj kotarskoj vlasti oštro osudile ova zbivanja i zatražile ispitivanje okolnosti naseljavanja navedenih Roma, te poduzimanje mjera u sprečavanju sličnih događaja. Državno tužiteljstvo u Osije-

\footnotetext{
kako današnji Romi-Bajaši vuku svoje porijeklo od Koritara, a današnji Romi koji govore „romano chibom“, vjerojatno, dijelom vuku svoje porijeklo od Kolompara; Franjo Fancev, „Iz prošlosti i sadašnjosti cigana“. Narodne novine, 18.11.1912., br. 267., 3.; Hrvatska Enciklopedija, 5. sv. (Zagreb 1941-1945), 2: 749, „Cigani“ (Viktor Horvat,...et.al); Zvonimir Pongrac, Gjelem, gjelem: zbirka ciganskih ili romskih pjesama i melodija (s pregledom povijesti i glazbe Roma) (Zagreb 2003.), 83.-84.

${ }^{10}$ Više o ovoj anketi vidi u radu: Danijel Vojak, „Anketa o kolonizaciji cigana” ili pokušaj koloniziranja Roma u Savskoj banovini, Časopis za suvremenu povijest 48 (2016), 2: 431-458.

${ }^{11}$ Vojak, U predvečerje rata, 195.
} 
ku je u srpnju 1942. podiglo optužnicu protiv devet pojedinaca pod optužbom za nasilje nad Romima, no nije poznat konačni ishod ovog slučaja. ${ }^{12}$

Uoči izbijanja Drugoga svjetskog rata u novinama se sve češće isticao strah stanovništva od Roma, posebice zbog njihovog kriminaliteta. Tako su se objavljivali brojni „bombastični“ naslovi članaka, poput „Narod strahuje od cigana“, „Cigani ugrožavaju imovinu seljaka“, „Ciganima treba već jednom stati na kraj“, „Što ćemo napokon sa ciganima“, „Kuda s ciganima“, „Kako se riješiti cigana - skitnica“" i sl. ${ }^{13}$ Pozadina ovih članaka bila je izvršiti pritisak prema banovinskim vlastima da „konačno“ urede položaj Roma. Tako se pisalo o tome da vlasti Banovine Hrvatske namjeravaju donijeti poseban zakon o Romima. ${ }^{14}$ No, ni u ovom slučaju nije došlo do njegovog sustavnog (cjelovitog) zakonskog rješenja, već je ono u takvom izrazito negativnom društvenom ozračju prema Romima dočekalo ustaške vlasti u NDH.

\section{Ukratko o položaju Roma u Nezavisnoj Državi Hrvatskoj, 1941. - 1945.}

Romsko stanovništvo je, uz Židove, Srbe i Hrvate antifašiste, bilo posebno pod udarom ustaške politike u travnju 1941. godine u novoosnovanoj NDH. ${ }^{15}$ Nije poznato da su ustaše prije preuzimanja vlasti imale posebno razrađenu politiku u odnosu prema Romima. No, naznaka te politike bila je vidljiva, između ostalog, početkom svibnja 1941. u varaždinskom listu $\mathrm{Hr}$ vatsko jedinstvo, gdje je istaknuta potreba progona Srba jer su „opasne i smrtonosne guje“, Židova kao „parazita - nametnika“ te Roma kao „nepoćudnih nametnika“, „,̌ireva“ i , ,izdajnika“. ${ }^{16}$ Istodobno, u javnim govorima i drugim javnim istupima istaknutih ustaških dužnosnika, poput Alije Šuljka i Mladena Lorkovića, Romi su bili isticani kao neprijatelji nove države te se pozivalo na

${ }^{12}$ Vojak, U predvečerje rata, 194-195; Državni arhiv u Osijeku, Državno odvjetništvo Osijek, sign. HR-DAOS-1309, kut. 9, br. 1088/42.

13 „Narod strahuje od cigana“, Jutarnji list, 1. VIII. 1939., br. 9884, 15; „Cigani ugrožavaju imovinu seljaka“, Jutarnji list, 6. IV. 1940., br. 10128, 16; „Ciganima treba već jednom stati na kraj“", Jutarnji list, 21. XII. 1940, br. 10386, 17; „Što ćemo napokon sa ciganima“, Seljački Dom, 13. II. 1941., br. 7, 4; „Kuda s ciganima“, Hrvatska obrana, 21. VII. 1940., br. 28, 6; „Kako se riješiti cigana - skitnica“, Hrvatsko zagorje, 11. X. 1940., br. 41, 6.

${ }^{14}$ M.M.Gr. [Milan M. Grujičić], „Cigansko pitanje i drugi narodi“, Balkan, 30. VI. 1937., br. 231, 4; Milan M. Grujičić, „I Hrvatska banovina rješava cigansko pitanje“, Novi Balkan, 2. VII. 1940., br. 3, 2; Vojak, U predvečerje rata, 104-111.

${ }^{15}$ Zločini na jugoslovenskim prostorima u Prvom i Drugom svetskom ratu: Zbornik Dokumenata, sv. 1 Zločini Nezavisne Države Hrvatske 1941. - 1945. (Beograd, 1993), XXXIII.

16 „Tri socijalno-politička problema“, Hrvatsko jedinstvo, 3. V. 1941., br. 185, 1. 
„definitivan obračun“s njima prisilnom kolonizacijom na jednome mjestu ili slanjem na prisilan rad. ${ }^{17}$

Prve naznake konkretne politike ustaških vlasti prema Romima predstavlja donošenje rasnih zakona krajem travnja 1941., poput „Zakonske odredbe o rasnoj pripadnosti“, „Zakonske odredbe o državljanstvu“ i ,Zakonske odredbe o zaštiti arijevske krvi i časti hrvatskog naroda“, u čijem je članku 4. jasno navedena rasna klasifikacija Roma. ${ }^{18} \mathrm{U}$ ovim je zakonima primjetan određeni utjecaj Nürnberških zakona, posebice u definiranju nearijevskog podrijetla romskog stanovništva. ${ }^{19}$ Kao jedan od provedbenih akata „Zakonske odredbe o rasnoj pripadnosti“ donesena je „Izjava o rasnoj pripadnosti“, popraćena „Uputom za sastav izjave o rasnoj pripadnosti“" u kojoj su Romi definirani kao pripadnici nearijevskih naroda. ${ }^{20}$

Znatan problem u provođenju politike prema Romima predstavljalo je pitanje utvrđivanja njihovog stvarnog demografskog stanja, kako bi se omogućilo daljnje provođenje mjera protiv Roma. ${ }^{21}$ Zbog toga su ustaške vlasti odlučile u ljeto 1941. provesti popisivanje Roma u NDH. U tom kontekstu je Ministarstvo unutarnjih poslova NDH 3. srpnja 1941. odredilo popisivanje Roma s točnim ,uputama““. ${ }^{22}$ Njima je predviđeno da se do kraja istoga mjeseca provede popisivanje Roma, pri čemu su se trebali prikupiti njihovi osobni podaci, a određeno je da se protjeraju oni nomadski Romi koji su ušli u NDH nakon njezina osnivanja. ${ }^{23}$ Istodobno s prikupljanjem demografskih podataka o Romima, ustaške vlasti su promišljale o potrebi koloniziranja Roma na jednom području NDH. No, od kolonizacije Roma odustalo se i u tome sluča-

${ }^{17}$ Savo Skoko, „Na tragičnoj stranputici“, u: Hercegovina u NOB / pišu učesnici, sv. 4 (april 1941. - juni 1942), (Ratna prošlost naroda i narodnosti Jugoslavije, knj. 285; Zbornik sjećanja, 103), ur. Rajko Šarenac (Beograd, 1986), 326; Slavko Vukčević, „Genocid u Nezavisnoj Državi Hrvatskoj 1941. - skrivena stvarnost“, Vojno-historijski glasnik 44 (1994), 1-2: 80-81.

${ }^{18}$ Lengel-Krizman, „Prilog proučavanju terora“, 30-32; Pavao Matijević, „Rasna pripadnost“, Glasnik biskupija bosanske i srijemske, 15. 4. 1942., 52-53.

${ }^{19}$ Mark Biondich, „Persecution of Roma - Sinti in Croatia, 1941. - 1945.“, u: Roma and Sinti: Under-Studied Victims of Nazism, ur. Paul A. Shapiro, Robert M. Ehrenreich (Washington, 2002), 34.

${ }^{20}$ Državni arhiv u Varaždinu, sign. HR-DAV-25, kut. 16, 1941, br. 9774/41.

${ }^{21}$ Slobodan D. Milošević, Izbeglice i preseljenici na teritoriji okupirane Jugoslavije 1941 1945. godine (Beograd, 1981), 240.

${ }^{22}$ Hrečkovski, „Progoni i deportacije“, 35.

${ }^{23}$ Milan Bulajić, Ustaški zločini genocida i suđenje Andriji Artukoviću 1986. godine, knj. 2 (Beograd, 1988), 83-84. 
ju, vjerojatno zbog nedovoljne spremnosti vlasti NDH za njezino provođenje uslijed sve težih ratnih (ne)prilika. ${ }^{24}$

Potrebno je istaknuti kako nije poznato da su tijekom 1941. godine ustaške vlasti sustavno ubijale romsko stanovništvo, iako su poznati slučajevi njihovih masovnih zločina nad Romima. Navedene ustaške zločine potrebno je promatrati u kontekstu njihovog sukoba s partizanskim pokretom, a Romi su bili kolateralne žrtve tih sukoba. ${ }^{25}$

Nakon provođenja popisivanja Roma i odustajanja od njihove kolonizacije u ljeto 1941., ustaške vlasti su se tek u svibnju 1942. odlučile na sljedeći korak u rješavanju onoga što su nazivali „,ciganskim pitanjem“. Tako je okružnicom Ministarstva unutarnjih poslova i odredbom Ustaške nadzorne službe, uz podršku Ravnateljstva za javni red i sigurnost, od 19. svibnja 1942. propisano prikupljanje svih Roma u NDH. ${ }^{26}$ Tada su započela masovna uhićenja i odvođenja Roma iz svih područja NDH, i to većinom željeznicom do logora u Jasenovcu.

\section{Romi u Slavoniji za vrijeme NDH}

$\mathrm{Na}$ temelju navedenog o položaju Roma uoči Drugoga svjetskog rata, logično je zaključiti kako su oni na slavonskim područjima bili pod asimilacijskim pritiscima banovinskih i lokalnih (općinskih) vlasti, koje su zajedno s tamošnjim stanovništvom negativno percipirale Rome kao besposličare, lijenčine, kriminalce i sl. To je sve dovodilo i do međusobnih izrazito nasilnih sukoba. U takvom je, negativnom i represivnom, ozračju romsko stanovništvo na slavonskim područjima dočekalo osnivanje NDH i uspostavu ustaške vlasti.

Nije poznato da se odmah nakon uspostave NDH promijenio odnos državnih i lokalnih vlasti prema Romima na slavonskim područjima, već je do takve promjene došlo postupno. Jedna od izravnih posljedica kratkotrajnog

${ }^{24}$ Danijel Vojak, „Počeci progona Roma u Nezavisnoj Državi Hrvatskoj ili o inicijativi Križevaca o potrebi 'odstranjenja' Roma“, u: Zbornik radova: Druga međunarodna konferencija Holokaust nad Jevrejima, Romima i Srbima u Drugom svetskom ratu, ur. Vojislav Vučinović (Beograd, 2015), 43-51.

${ }^{25}$ Adam Dupalo, Banija i Sisak u NOP-u 1941: događaji, svjedočanstva, dokumenti (Zagreb, 2014), 71, 218-219, 262; Dušan Baić, Kotar Vrginmost u NO borbi: 1941-1945. (Vrginmost, 1980), 262, 445-446, 597-599, 857; Božo Vukobratović, „Teror i zločini fašističkih okupatora i njihovih pomagača na Kordunu 1941.“, u: Simpozij o Petrovoj gori: u povodu 25-godišnjice III zasjedanja ZAVNOH-a, Topusko, 10. - 13. studenog 1969., ur. Dušan Čalić (Zagreb, 1972), 360; Bogdanka Romčević, „Žrtve fašističkog terora i rata s područja kotara Vojnić 1941-1945.“, u: Kotar Vojnić u narodnooslobodilačkom ratu i socijalističkoj revoluciji, ur. Đuro Zatezalo (Karlovac, 1989), 1276-1279; Lengel-Krizman, Genocid nad Romima, 40-41.

${ }^{26}$ Vladimir Dedijer, Vatikan i Jasenovac: dokumenti (Beograd, 1987), 302-303; Lengel-Krizman, Genocid nad Romima, 41-42. 
travanjskog rata, u kojem je vojska Kraljevine Jugoslavije kapitulirala, bilo je pitanje zaustavljanja epidemija među vojnim konjima. Tako je Odsjek za veterinarstvo Ministarstva za narodno gospodarstvo NDH izdao početkom svibnja 1941. naredbu o obvezatnoj maleinizaciji vojnih konja, ali i konja u vlasništvu Roma, kojima je dodatno propisana zabrana prisustvovanja sajmovima. ${ }^{27}$ Nekoliko dana nakon toga, osječke gradske vlasti traže od tamošnjeg Predstojništva gradskog redarstva da uklone Rome s području oko groblja od Novog grada, jer su se tamo u posljednje vrijeme naselili, na što se tamošnje stanovništvo žali, tužeći se na mogućnost izbijanja stočnih zaraza i „drugih neprilika“" ${ }^{28}$ Nije poznato je li se provelo uklanjanje novonaseljenih Roma, no osječke su gradske vlasti u drugom dokumentu izvijestile u lipnju 1941. kako na njihovom gradskom području nema „nastanjenih cigana“, što sugerira kao su ovi Romi bili protjerani. ${ }^{29} \mathrm{No}$, zanimljivo je kako se stanovništvo negativno odnosilo prema Romima, ističući ih kao moguće širitelje stočnih zaraza. Problem sa sprečavanjem širenja zaraznih bolesti među romskim konjima na području Velike župe Baranja nastavio se, o čemu svjedoči odredba spomenutih župskih vlasti s kraja listopada 1941. Njome se propisuje zabrana Romima da trguju konjima, provođenje popisa „svih ciganskih konja“, obvezni periodični veterinarski pregledi romskih konja, zabrana izdavanja „marvinskih putnica“ Romima i dr. Baranjske su župske vlasti kao razloge za provođenje ove odredbe navele „da se sprieči nelegalna trgovina i kriumčarenje konja te raznašanje stočnih zaraza uopće a sakagije i šuge konja napose, po ciganima“".${ }^{30}$ Odredbe $o$ ograničavanju romske trgovine konjima u kontekstu sprečavanja stočnih zaraza u novoj državi nisu bile ništa neuobičajeno, već jedna od kontinuiranih politika veterinarskih službi. ${ }^{31}$ No, nekoliko mjeseci nakon uspostave nove države vlasti su donijele odluke o isključivanju Roma od vojne obveze. Tako je Osječko popunidbeno zapovjedničtvo početkom rujna 1941. u dopisu Općinskom poglavarstvu Čepin odredilo izuzimanje Roma od tamošnjeg novačenja. ${ }^{32}$

Vlasti NDH u Slavoniji slijedile su anticiganistički model progona koji su provodile središnje vlasti u Zagrebu. Ovaj model se sastojao od nekoliko faza, a bio je temeljen na rasnim zakonima kojima su Romi bili potisnuti izvan zaštite vlasti. Nakon toga su središnje vlasti nastojale oblikovati svoje rješenje

${ }^{27}$ Državni arhiv u Osijeku, Fond Gradsko poglavarstvo Osijek, sign. HR-DAOS-10 (dalje HRDAOS-10), kut. 5195, br. 25390/41.

${ }^{28}$ Državni arhiv u Osijeku, Fond Poglavarstvo Slobodnog i kraljevskog grada Osijeka, sign. HR-DAOS-6 (dalje HR-DAOS-6), kut. 39, br. 30539/1941.

${ }^{29}$ HR-DAOS-6, kut. 5835, br. 23053/41.

${ }^{30}$ HR-DAOS-10, kut. 5253, br. 61591/41.

${ }^{31}$ Vojak, U predvečerje rata, 138-139.

32 Državni arhiv u Osijeku, Fond MO Čepin, sign. HR-DAOS-40 (dalje HR-DAOS-40), kut. 18, br. 919/1941. 
„ciganskog pitanja“, a jedan od preduvjeta za to bilo je utvrditi broj Roma na području NDH. Stoga je i izdana naredba u srpnju 1941. o prikupljanju podataka o popisivanju Roma, što se provodilo i na slavonskom području. Popisi Roma provedeni su od sredine srpnja 1941. do kraja kolovoza iste godine, a pritom se osim samog broja Roma bilježilo mjesto stanovanja, godine starosti, spol, a pridodana je i rubrika „Opaska“ u kojem se bilježilo žive li Romi na vlastitom zemljištu i/ili kući, ili žive na općinskom zemljištu, te način života (radi li se o nomadstvu ili stalnom naseljavanju) i zanimanje.

U razdoblju od uspostave NDH do svibnja 1942., kada su vlasti odlučile deportirati sve Rome u jasenovački logor, nisu bile zabilježene masovne deportacije i ubijanja romskog stanovništva na području Slavonije, za razliku od takvih slučajeva na karlovačkom i kordunskom području. ${ }^{33}$ Štoviše, u tom razdoblju bilo je uočljivo kako središnje vlasti nemaju posebnu oblikovanu politiku prema Romima, izuzev postojećih restrikcija temeljenih na rasnim i drugim zakonima.

Ministarstvo unutarnjih poslova NDH, Ustaška nadzorna služba i Ravnateljstvo za javni red i sigurnost 19. su svibnja 1942. odredile deportaciju svih Roma iz NDH u jasenovački logor. Na temelju toga su ustaške lokalne vlasti zajedno s redarstvom i vojskom započele deportirati Rome. U hrvatskoj javnosti deportacija Roma bila je predstavljena kao konačno rješavanje „ciganskog pitanja“, unutar čega će se Romi "privesti radu“ i ,zanatski osposobiti“. Tako Nova Hrvatska izvješćuje početkom lipnja 1942. kako „cigansko pitanje, o kojem se raspravljalo čitav niz godina, konačno je riješeno. Nakon brojnih anketa, tisuće novinskih članaka i predloga, sad su oblasti ozbiljno povele računa o ciganima, koji su nomadskim i skitničkim životom zadavali brige selima i gradovima. Stalno se pitalo, kad će prestati skitanje, prosjačenje, nered i varanje s tajanstvenim blagom i ljubavnim napitcima, te kradje sijena i drugih stvari. Na cestama smo - još pred godinu dana - često gledali stalne selidbe cigana. Brojne skupine s kolima prolazile su iz jednog kraja u drugi, gdje su nicali ciganski šatori. Upravo je neugodno bilo promatrati odrpanu odjeću cigana. Ciganke - koritarke su prolazile u svakojakim haljinama, a njihova mnogobrojna djeca su bila upravo gola. Svi su prljavi i zapušteni, a osobito ciganska djeca su puna nečistoće. Ljudi su se upravo čudili izgledu tih cigana, koji su živjeli na primitivan način. Njihova vanjština, nerad i nered - to sve je loše djelovalo na strance, koji su putovali našim cestama. Sada se pristupilo rješavanju ciganskog pitanja. Ovo pleme prestati će svojim dosadanjim vjekovnim načinom života“. 34

${ }^{33}$ Danijel Vojak, „Zaboravljene žrtve Drugog svjetskog rata ili o stradanju Roma u Nezavisnoj Državi Hrvatskoj, 1941. - 1945“, u: Jasenovac: manipulacije, kontroverze i povijesni revionizam, ur. Andriana Benčić, Stipe Odak, Danijela Lučić (Jasenovac, 2018), 259-260.

${ }^{34}$ „Hrvatska se sela čiste od cigana“, Nova Hrvatska, 3. VI. 1942., br. 205, 8. 
U takvom kontekstu odvijala se deportacija na slavonskom području. Tako su 29. svibnja 1942. deportirani Romi iz Ladimirevaca i Petrijevaca (kotar Valpovo). Početkom lipnja iste godine zemunska policija deportirala je oko 400 Roma u Jasenovac, a ogulinske su vlasti tada deportirale 127 Roma u isti logor. ${ }^{35}$ Poznate su i deportacije Roma iz Đakova, Orahovice, Našica, Podravske Slatine, Daruvara, Virovitice (iz sela Budanice odvedena su 33 Roma 8. kolovoza 1941., ${ }^{36}$ a Romi su odvedeni i iz romskoga Kapetanova Sela kod Suhopolja početkom rujna 1942.), ${ }^{37}$ Grubišnog Polja, Slavonske Požege, Broda na Savi (Slavonskog Broda), Nove Gradiške, Novske. ${ }^{38}$ Deportacije Roma odvijale su se i nakon ljeta 1942. Tako su vlasti NDH 15. listopada 1942. deportirale 10 Roma iz Slakovaca (kod Vinkovaca) u Jasenovac. ${ }^{39}$

Prema poznatim izvorima, u samim deportacijama Roma sudjelovale su većinom ustaške lokalne vlasti potpomognute redarstvenicima i žandarima te domobranskim vojnicima i folksdojčerima. Ivan Bauer je u svom iskazu iz kolovoza 1951. opisao na koji su način bili deportirani Romi iz sela Strizivojna (đakovački kotar). Njemu su kao tamošnjem općinskom bilježniku u lipnju 1942. došli žandari i ,tražili da im ja dajem našu seosku stražu koja će im navečer biti potrebna. S početka mi nisu htjeli kazati radi čega oni tu stražu trebaju, no kasnije su mi rekli da su dobili nalog od kotara, a kotar od župe, da na večer odnosno po noći imaju provesti u logor sve Cigane koji borave na teritoriju sela Strizivojna. Ja sam odmah obavijestio stražare i dao žandarima u pomoć. $\mathrm{Na}$ večer istoga dana, odnosno po noći, kada su svi cigani spavali, žandari su ih razbudili, sve pohapsili i otjerali u jasenovački logor (...) ti cigani bili su iznenadjeni, jako zaplašeni i nisu davali nikakova otpora, te su se pokoravali naredjenjima žandara i sutradan su bili sprovedeni u jasenovački logor““.40

Zanimljivo je svjedočanstvo Stjepana Ivića, načelnika valpovačke općine za vrijeme Drugog svjetskog rata, koji je u svom iskazu iz ožujka 1951. svje-

${ }^{35}$ Biondich, „Persecution of Roma“, 36; Mihael Sobolevski, „Konzultirati dopunske izvore“, Naše teme 30 (1986), 9: 1285; Đuro Šovagović, Josip Cvetković, Valpovština u revoluciji (Kronika revolucionarnih zbivanja 1918-1945.) (Valpovo, 1970), 101, 104.

${ }^{36}$ Luka Šteković, Romi u virovitičkom kraju (Beograd, 1998), 18.

${ }^{37}$ Isto, 36.

${ }^{38}$ Hrečkovski, „Progoni i deportacije“, 36; Dušan Lazić-Gojko, Sremsko krvavo leto 1942. (Sremska Mitrovica, 1982), 49-51, 298-300; Filip Škiljan, „Stradanje Srba, Roma i Židova u virovitičkom i slatinskom kraju tijekom 1941. i početkom 1942. godine“. Scrinia Slavonica, 10 (2010), 349; Mihael Sobolevski, „Ustanak na dijelu kotara Ogulin 1941 i početkom 1942. godine“, u: Prva godina narodnooslobodilačkog rata na području Karlovca, Korduna, Gline, Like, Gorskog kotara, Pokuplja i Žumberka, ur. Đuro Zatezalo (Karlovac, 1971), 911.

${ }^{39}$ Ivan Karaula, „Žitelji Slakovaca stradalnici Drugog svjetskog rata i poraća“, Hrašće 2 (1997), 5: 74.

${ }^{40}$ Hrvatski državni arhiv, sign. HR-HDA-421 (dalje HR-HDA-421), Fond Javno tužilaštvo SR Hrvatske, Optužnica Pavelić - Artuković, kut. 128, Ivan Bauer. 
dočio: „... poznato mi je da su polovicom 1942. god. tjerani Jugoslavenski građani Cigani. Nalog za tjeranje izdao je kotarski predstojnik Gebauer, od koga je on dobio nalog neznam. Cigani su tjerani na večer, no neznam koliko je obitelji otjerano, ali znam da ih je dosta otjerano. Otjerani su prvo u Bizovac, a odanle vlakom navodno u koncentracijski logor Jasenovac ili Gradišku. Poslije, kada su Cigani otjerani, pitao sam kako je došlo do njihovog tjeranja, i mislim, da mi je bilježnik Adamčić rekao da je osnovu za njihovo tjeranje Uredba o nepoćudnim licima. Nisam čuo kakova je sudbina Cigana, no znam, da se pričalo da su nestali, ali znam, da se nisu uopće vratili nazad...". ${ }^{41}$ Anka Ililibašić iz Tenje slično je svjedočila o deportaciji Roma iz njezinog mjesta, navodeći kako su „ustaše i žandari“ pokupili sve Rome, „i najstarije i najmladju djecu, pa čak i one koji još nisu prohodali i tako sakupivši ih protjerali iz Tenje u logor Jasenovac". ${ }^{42}$

Oružnička postaja iz Vilić Sela obavijestila je kotarske vlasti u Požegi kako je 6. lipnja 1942. uhitila na području općine Brestovac šest romskih obitelji koje su putovale u smjeru Nove Gradiške. ${ }^{43}$ Logično je za pretpostaviti kako su ove romske obitelji nastojale izbjeći deportaciju u jasenovački logor, koja se prije nekoliko dana provela na širem požeškom području. No, oružnici su ih uhvatili i tražili od nadležnih vlasti da odrede kako s njima postupati. U skladu s tadašnjom odredbom o deportaciji svih Roma u NDH u jasenovački logor, kotarske vlasti u Požegi naredile su oduzimanje imovine uhićenim Romima. Tako su općinske vlasti u Požeškom Brestovcu zaplijenile romske konje, kola i orme, koje su predale na „prehranu i upotrebu“ tamošnjim stanovnicima. ${ }^{44}$

Dio Roma uspio je izbjeći deportaciju. Jedan od takvih slučajeva bio je onaj u Valpovu, preciznije rečeno s Romom Nikolom Petrovićem iz Valpova, kojeg su ustaše ,polovinom 1942.“ u postupku deportacije u jasenovački logor izdvojile uz još četiri romske obitelji, kako bi obavljali posao ,seoskih čobana i živodera" u Bizovcu, te ih time spasile od deportacije. Nekoliko mjeseci kasnije valpovačke kotarske vlasti odlučile su deportirati ostale Rome, no njega je sakrio jedan Valpovčanin, čime mu je spasio život. ${ }^{45}$ Stjepan Mitrović iz Bistrinaca (valpovački kotar) djelomično je potvrdio prethodno opisanu priču Nikole Petrovića, navodeći kako su dvije romske obitelji iz deportacijskog transporta u Bizovcu „vraćene“ u Bistrince radi „,̌išćenja nužnika“ u tom se-

\footnotetext{
${ }^{41}$ HR-HDA-421, kut. 128, Stjepan Ivić.

${ }^{42}$ HR-HDA-421, kut. 128, Anka Ililibašić.

${ }^{43}$ Državni arhiv u Požegi, sign. DASB-PŽ-16 (dalje DASB-PŽ-16), Fond Kotarska oblast u Požegi, Opći spisi, 1942., kut. 20, br. 10779.

${ }^{44}$ DASB-PŽ-16, kut. 20, br. 10720.

${ }^{45}$ HR-HDA-421, kut. 128, Nikola Petrović.
} 
lu ${ }^{46}$ Slično je svjedočio i Stjepan Ivić, navodeći kako su valpovačke općinske vlasti prilikom deportacija Roma tražile ostanak četiriju romskih obitelji, no usprkos ovoj molbi oni su bili deportirani u jasenovački logor. Jedini je bio pošteđen Nikola Petrović. ${ }^{47}$ Rom Janko Nikolić je u svom iskazu iz kolovoza 1951. spomenuo kako je on zajedno s trojicom Roma bio „pošteđen“ deportacije Roma iz Donjeg Miholjca u svibnju 1942., jer su bili izdvojeni radi obavljanja ,živoderskih poslova“, a jedan od njih zbog intervencije neroma. Mjesec dana kasnije iste su kotarske vlasti odlučile preostale Rome deportirati u jasenovački logor, no Janko je ponovno bio pošteđen deportacija jer mu je supruga bila Hrvatica. ${ }^{48}$

\section{Oduzimanje romske imovine}

Potrebno je napomenuti kako je većina romskog stanovništva u međuratnom razdoblju živjela na marginama gospodarskog života na hrvatskim područjima. Zasigurno, osnivanje NDH nije doprinijelo unapređenju gospodarskog položaja Roma, jer su oni na temelju raznih zakona bili isključeni iz društva te time i gospodarskog djelovanja. No, dio Roma posjedovao je kuće, zemljišta i drugu vrijednu imovinu, koja im je bila oduzeta za vrijeme njihove deportacije. Tako su državne i lokalne institucije nakon deportacija Roma preuzimale njihovu imovinu.

Ured za kolonizaciju u Osijeku poslao je 11. lipnja 1942. okružnicu, između ostalih, i nadležnim lokalnim vlastima, u kojoj se navodi kako će Zavod za kolonizaciju u Zagrebu preuzimati posjede ,izseljenih ciganskih obitelji“, te će izraditi popis svih ,izseljenih ciganskih obitelji“"s njihovom imovinom. ${ }^{49}$ Gradsko poglavarstvo Osijek nekoliko dana kasnije obavijestilo je nadležni Ured za kolonizaciju kako u Osijeku nema „,ciganskih naseobina“.$^{50}$ Za pretpostaviti je kako su lokalne vlasti sustavno prikupljale ove podataka, posebno imajući na umu potencijalnu materijalnu korist od prodaje imovine deportiranih Roma. Ovaj proces oduzimanja romske imovine može se vidjeti na primjeru sela Čađavica (kotar Donji Miholjac). Romi iz Čađavice deportirani su u lipnju 1942. u jasenovački logor. Njihovu imovinu odmah su preuzele lokalne i središnje vlasti. Na području sela Čađavica djelovalo je Povjerenstvo Ureda za kolonizaciju u Osijeku za kotar Donji Miholjac, koje je 12. lipnja 1942. donijelo privremenu odluku o dodjeli triju napuštenih romskih kuća

\footnotetext{
${ }^{46}$ HR-HDA-421, kut. 128, Stjepan Mitrović.

${ }^{47}$ HR-HDA-421, kut. 128, Stjepan Ivić.

${ }^{48}$ HR-HDA-421, kut. 128, Janko Nikolić.

${ }^{49}$ HR-DAOS-10, kut. 5339, br. 29405/42.

${ }^{50}$ Isto.
} 
s pripadajućim poljoprivrednim zemljištem jednom stanovniku iz Čađavice, jednoj stanovnici Krčenika i jednoj stanovnici Čađavičkog Luga. U nastavku odluke propisana su prava i obveze novih (privremenih) „vlasnika“, poput visine naknade za obradu zemljišta. ${ }^{51}$ Istog dana je u Zapisniku o preuzimanju imanja deportiranih Roma naznačeno kako navedene osobe ulaze u posjed, ali se u kućama ne nalaze „nikakve nepokretne stvari iseljenih cigana“, jer su one ,preuzete i pohranjene“ u općinskom poglavarstvu. ${ }^{52}$ Drugim riječima, općinske vlasti su prvo „preuzele“ i potpuno „očistile“ od ikakve imovine romske kuće, koje su onda dale na privremeno korištenje uz određenu cijenu. Iz ovoga se jasno može vidjeti na koji su sve način „materijalno profitirale“ općinske vlasti od imovine deportiranih Roma. Značajan je dopis Općinskog poglavarstva u Čađavici od 9. srpnja 1942., upućen Uredu za kolonizaciju u Osijek pod naslovom „Preuzimanje i obrada ciganskih posjeda“. U njemu se, između ostalog, navodi kako je drugi dan nakon deportacija Roma prodana njihova imovina, i to za svotu od 8935 kuna, koja je predana u tamošnju općinsku blagajnu. Unutar ovog iznosa odvojen je dio poreza za lokanu vlast, a pritom su općinske vlasti otkupile pšenicu i kukuruz s romskih polja i svu tu svotu proslijedile kotarskim vlastima u Donjem Miholjcu. ${ }^{53}$ Zanimljivo je da se $\mathrm{u}$ istom dopisu istaknula romska nekretnina pod kućnim brojem 6 , za koju se smatralo da bi je trebalo urediti za općinskog liječnika. Dopis završava upitom prema Uredu za kolonizaciju oko toga što uraditi s dugom općine prema Romu Dragutinu Bošnjaku u visini od 8000 kuna. Nije poznat odgovor Ureda za kolonizaciju, no logično je pretpostaviti kako je taj dug bio izbrisan uslijed toga što je navedeni Rom vjerojatno bio ubijen u jasenovačkom logoru. ${ }^{54} \mathrm{U}$ nastavku spisa o oduzimanju imovine Roma iz Cađavice pridodan je „Popis izseljenih ciganskih obitelji i preostale imovine“. U njemu je popisano šest romskih obitelji koje su se prezivale Goman. Iz navedenog dokumenta uočljivo je kako su romske obitelji u prosjeku imale 1 jutro poljoprivrednog zemljišta sa zgradom i manjim brojem domaćih životinja (perad, konji, svinje). Popisan je bio i njihov skromni namještaj, koji se sastojao od stolova sa stolcima, kreveta i ormara. U opasci u posljednjoj rubrici tablice naznačeno je da su im sve domaće životinje prodane. ${ }^{55}$ Potrebno je istaknuti na koje je sve pravne načine Zavod za kolonizaciju u Zagrebu preuzimao romske posjede. U dva zapisnika od prosinca 1942. zabilježen je iskaz dvoje seljaka iz Čađavice, koji se navode kao prodavatelji posjeda deportiranih Roma, a koji sada

\footnotetext{
${ }^{51}$ Državni arhiv u Osijeku, sign. HR-DAOS-52 (dalje HR-DAOS-52), Fond Ured za kolonizaciju Osijek, kut. 1, br. 24/42.

${ }^{52}$ Isto.

${ }^{53}$ HR-DAOS-52, kut. 2, br. 29-31.

${ }^{54}$ Isto.

${ }^{55}$ Isto.
} 
pristaju na ,prijenos“ posjeda u korist navedenog zavoda. To je ustvari značilo svojevrsno poništenje imovinskog prava deportiranih Roma, čime se omogućio pravni prijenos vlasništva državi. ${ }^{56} \mathrm{U}$ drugim slučajevima romski posjedi predavali su se određenim pojedincima, dok se druga nepokretna imovina Roma nudila na javnim dražbama, gdje ju je lokalno stanovništvo kupovalo po „bagatelnim cijenama“. ${ }^{57}$ Time je upravljao Ured za kolonizaciju, točnije njegov V. Odjel za podržavljeni imetak, a njime Državna riznica NDH. Tako je Ured za kolonizaciju u Osijeku, između ostalog, preuzeo posjede 63 iseljene romske porodice, što sugerira kako je dio Roma, poput Židova ili Srba, bio znatno materijalno oštećen prilikom deportacija u jasenovački logor. ${ }^{58}$

\section{Romi sa slavonskog područja u jasenovačkom logoru}

Potrebno je napomenuti kako su vlasti NDH preuzele rasno-nacionalna zakonodavna rješenja po uzoru na nacistička te organizirale sustav logora u kojima su nastojale koncentrirati određene neželjene skupine stanovništva. ${ }^{59}$ Jedan od tih logora bio je izgrađen u Jasenovcu i u njemu su bile smještene posebne skupine zatočenika, među kojima su bili i Romi. ${ }^{60}$

Ukratko je potrebno istaknuti kako se Rome, za razliku od drugih zatočenika, nije službeno bilježilo pojedinačno, već kao dio određenoga ,željezničkog vagona“. Svima njima je po dolasku u Jasenovac oduzeta (opljačkana) sva osobna imovina. Neki preživjeli neromski zatočenici, poput Zorka Goluba i Daniela Kovačevića, spominju kako je Romima tada oduzeta znatna količina dukata, novaca, nakita, glazbala, konja i dr. ${ }^{61}$ Po dolasku u jasenovački logor Romi su bili podijeljeni na dvije skupine: nemoćni, bolesni, žene i djeca nalazili su se u skupini $3 b$, a ,jači i izdržljiviji“ Romi u skupini $3 c .{ }^{62}$ Romi su unutar jasenovačkoga logorskog sustava bili smješteni u sjeveroistočnom

56 Isto.

${ }^{57}$ Milan Bulajić, „Ustaški zločini genocida protiv Cigana (Roma) u Drugom svjetskom ratu“, u: Razvitak Roma u Jugoslaviji: problemi i tendencije: zbornik radova sa naučnog skupa održanog 12. i 13. januara 1989. godine, ur. Miloš Macura (Beograd, 1992), 100, 107, 113, 118-119, 120, 125, 128.

58 Ivan Balta, ,Kolonizacija u Slavoniji od početka XX. stoljeća s posebnim osvrtom na razdoblje 1941.-1945. godine“, Radovi Zavoda za povijesne znanosti HAZU u Zadru 43 (2001), 469-470.

59 Mario Kevo, „Počeci logora Jasenovac“, Scrinia Slavonica 3 (2003), 472-473.

${ }^{60}$ Kevo, „Počeci logora“, 473-478; Nataša Matušić, Jasenovac 1941.-1945.: logor smrti i radni logor (Jasenovac; Zagreb, 2003), 18-26.

${ }^{61}$ Daniel Kovačević, „Prvi dan u logoru Jasenovac“, u: Riječi koje nisu zaklane, ur. Simo Brdar (Jasenovac, 1989), 117-118, 120.

${ }^{62}$ Kevo, „Počeci logora“, 480; Lengel-Krizman, Genocid nad Romima, 67-68. 
dijelu logora, koji je nazvan Logor III C [C = ciganski $].{ }^{63}$ Drugi je dio Roma u početku bio smješten u selu Uštica u iseljenim srpskim kućama, no ubrzo je zbog njihova prekomjernog broja dio premješten u prekosavsko selo Gradina, u kojemu su se provodile najmasovnije likvidacije. ${ }^{64}$

Znatan dio Roma sa slavonskih područja bio je deportiran u jasenovački koncentracijski logor. Brojni preživjeli jasenovački svjedoci slažu se kako je većina romskih zatočenika ubijena u svega nekoliko mjeseci. Jedan od svjedoka zločina u Jasenovcu, Jovan Živković, primjećuje sljedeće: ,... ako ćemo govoriti o nečemu, o genocidu, onda su Cigani imali prvenstvo i nijedan nije ostao živ. Onoga koji nije mogao raditi, ubijali su odmah i nisu imali nikakvu šansu. Još Jevreji i Srbi u okviru ostatka logora su imali šansu, ne znam kakvu. Cigani nisu imali nikakvu šansu..." ${ }^{65}$ Slično njemu primjećuje Milko Riffer kao jasenovački logoraš, navodeći: ,...većina je Cigana odmah u početku likvidirana. Kasnije, kad su počeli radovi na nasipu, upotrebljavali su se Cigani tamo za najteže poslove. Svaki dan je na nasipu ostavljalo na desetine Cigana svoje kosti. Smatrali su ih za životinje niže vrsti, nešto kao miševe, čije je tamanjenje bilo ne samo dozvoljeno, nego se i preporučivalo. Za smrt Ciganina nije odgovarao ni logoraš, a kamoli ustaša. - Ubiješ li Ciganina, učinio si korisno djelo, kao da si prignječio noktom stjenicu“ “.66

Dio preživjelih slavonskih romskih logoraša iz Jasenovca nakon rata svjedočio je o tome što se dogodilo Romima u jasenovačkom logoru. Tako je Rom Tomo Nikolić iz Strizivojne (kotar Đakovo) nakon Drugog svjetskog rata svjedočio kako su ga žandari u kolovozu 1942. deportirali zajedno s drugih šezdesetak Roma u jasenovački logor. Nikolić zatim opisuje dolazak u jasenovački logor, navodeći: „... kada smo došli na stanicu [u Jasenovcu, op.a.] žandari su od nas silom oduzimali novčanike i iz novčanika sav novac koji smo u njima imali, tako da smo ostali sasvim bez novaca. Čim smo došli u Jasenovac ja sam upitao jednog ustašu neka mi objasni radi čega smo došli a on mi je odgovorio vidjeti ćete što će sa vama biti. Nakon kratkog vremena vidio sam jednog ustaškog oficira i njemu rekao da nisam ciganin a on je mene i još nekolicinu odvojio sa našim familijama od ostalih cigana. Logor u kojem sam se ja nalazio bio je odvojen od ciganskog logora jednom žicom, odnosno cigani su spavali na otvorenom zemljištu i nisu imali nikakovih kuća niti bilo kakvih baraka. Svake noći od 10 do 1 sat čuo sam strašan vrisak u ciganjskom logoru, a poslije toga sam čuo kako ustaše idu i pjevaju. Sutradan vidio sam da su kola kojima sam ja po dana prevažao neke predmete, sva krvava i u njima je

\footnotetext{
${ }^{63}$ Milko Riffer, Grad mrtvih: Jasenovac 1943. (Zagreb, 1946), 38.

${ }^{64}$ Lengel-Krizman, Genocid nad Romima, 47-48.

${ }^{65}$ Bulajić, Jasenovac: ustaški logori, 128.

${ }^{66}$ Riffer, Grad mrtvih, 155.
} 
znalo biti i ženskih kosa. Čuo sam da su cijele noći ta kola radila i išla u pravcu jedne šume, pa vjerujem, da su ustaše tamo svoje žrtve zakapali. Odvodjene cigana se je vršilo kroz dvije noći a poslije tog vremena nisam više vidio niti jednog...". ${ }^{67}$ Sam Nikolić se spasio tako da je uspio uvjeriti ustaške logorske vlasti da nije Rom, a kasnije su ga i pustili iz logora. Zanimljivo je i svjedočanstvo Roma Nikole Petrovića iz Valpova, koji navodi kako je tamo prije rata živjelo 81 domaćinstvo stalno naseljenih Roma. Prema Petroviću, sredinom 1942. lokalne ustaške vlasti su deportirale Rome u ,jasenovački koncentracijski logor", i to su prvo svi „bez obzira na spol i starost" bili transportirani u selo Bizovac, a onda u Jasenovac. Kasnije se saznalo kako su svi deportirani valpovački Romi bili ubijeni u navedenom logoru, a njihova imovina je bila oduzeta u korist vlasti. ${ }^{68}$

Jedan dio Roma sa slavonskih područja bio je deportiran u nacističke logore izvan NDH. Takav je bio slučaj s Romom Stevom Mitrovićem iz Novih Jankovaca, koji je bio deportiran u jasenovački logor sredinom 1942., a iz njega je uspio pobjeći. No, nakon dvadeset dana njemačka vojska ga je uhitila kod Grubišnog Polja te je poslan u logor u Novoj Gradišci. Nakon toga deportiran je u logore u Linzu, Berlinu i Beču. ${ }^{69}$ Rom Bogdan Goman iz sela Čađavice bio je vojnik Kraljevine Jugoslavije, zarobljen i odveden u logore u Njemačkoj, odakle se nakratko vratio u rodno selo, da bi ustanovio da su svi tamošnji Romi deportirani. ${ }^{70}$

\section{Sudjelovanje Roma iz Slavonije u antifašističkom pokretu}

Pitanje sudjelovanja Roma u jedinicama partizanskog pokreta jedno je od brojnih područja iz toga razdoblja koja nameću potrebu iscrpnijega znanstvenog istraživanja. Romi su se na prostoru mnogih europskih zemalja priključili partizanskom pokretu, i to u Srbiji, Italiji, Francuskoj, Slovačkoj, Crnoj Gori, Bugarskoj, Makedoniji, Grčkoj i Albaniji. ${ }^{71}$ Glede područja jugoslavenskoga partizanskog pokreta, neki znanstvenici koji su se bavili istraživanjem sudjelovanja nacionalnih manjina u partizanskom pokretu ne spominju Rome. Prvenstveno navode slučajeve sudjelovanja mađarske, slovačke i njemačke manjine u partizanskim jedinicama, dok Rome spominju samo uzgredno. ${ }^{72}$

\footnotetext{
${ }^{67}$ HR-HDA-421, kut. 128, Tomo Nikolić.

${ }^{68}$ HR-HDA-421, kut. 128, Nikola Petrović.

${ }^{69}$ HR-HDA-421, kut. 128, Stevo Mitrović.

${ }^{70}$ HR-HDA-421, kut. 128, Bogdan Goman.

${ }^{71}$ János Bársony, „Povijest Roma u 20. stoljeću i u doba Pharrajimosa“, u: Pharrajimos: sudbina Roma u doba Holokausta, ur. János Bársony, Ágnes Daróczi (Zagreb, 2013.), 37.

${ }^{72}$ Martin Kaminski, „NOP i nacionalne manjine“, u: Slavonija u narodnooslobodilačkoj borbi (Materijali naučnog skupa 25. i 26. novembra 1966. povodom 25-godišnjice ustanka), ur.
} 
Romi su se odupirali suradnji s ustaškim vlastima, kao što to pokazuje primjer na širem području Grubišnog Polja, gdje neki navode kako za vrijeme čitavog rata nijedan Rom nije bio u ustašama. ${ }^{73}$ Zanimljiv je slučaj stvaranja prve „ciganske partizanske jedinice“ u daruvarskoj okolici. U srpnju 1942. partizani su pronašli nekoliko romskih porodica, ukupno četrdesetak osoba, u šumi između Kreštelovca i Goveđeg Polja (područje Daruvara) koje su onamo pobjegle zbog straha od ustaških deportacija. Krsto Bosanac tada je uime partizana stupio u kontakt s njima, a prisjeća se kako: ,... sredinom jula 1942. godine saznalo se u partizanima da se u jednoj šumi između Kreštelovca i Goveđeg Polja, u ravničarskom dijelu daruvarske općine, krije nekoliko romskih porodica koje su se spasile od ustaškog terora i odvođenja u jasenovački logor. Upućen sam tamo da uspostavim s njima kontakt i da ih privolim da se sklone na sigurnije mjesto, na Papuk, a da se sposobni priključe partizanima, u borbi. To sam i učinio jedne noći. Zatekao sam oko 40-tak muškaraca, žena i djece - gladnih, prestrašenih i nepovjerljivih. Imali su od oružja tri lovačke puške, nekoliko sjekira. Do tada su živjeli na raznim mjestima daruvarske i garešničke općine. Ne mogu se danas sjetiti ni jednog imena ni prezimena tih Roma. Njihov dolazak na slobodno partizansko područje organizirao je poslije netko drugi, a u augustu ili septembru 1942. godine u Bijeloj, gdje su se smjestili, formiran je romski partizanski vod od petnaestak boraca. Oni se nisu htjeli odvajati od svojih porodica, a po onome što sam saznao kasnije od boraca, najčešće su izvršavali zadatke rekvizicije oružja i materijalnih dobara od neprijateljski nastrojenih stanovnika u ravničarskom dijelu daruvarske općine koji je bio pod kontrolom neprijatelja. Izvršavali su te zadatke, koliko se sjećam usputno dobivenih informacija, uspješno i vrlo savjesno. Ova romska jedinica, sigurno ne jača od voda, djelovala je u Bijeloj kratko, možda do jeseni 1943., jer su pojedini njeni borci upućivani u veće partizanske jedinice, a njihove porodice su se zajedno sa srpskim stanovništvom ovog kraja povlačile pod naletima neprijatelja dublje na Papuk “ ${ }^{74}$

Prema dostupnim izvorima može se primijetiti kako je dio Roma aktivno sudjelovao u partizanskom pokretu. Neki tumače njihovo sudjelovanje u tom pokretu kao reakciju na ustaško nasilje nad njima, posebice sredinom 1942., kada su se odvijale masovne deportacije Roma u jasenovački logor. ${ }^{75}$

Martin Kaminski (Slavonski Brod, 1967), 171-182; „Stenografski zapisnik“, u: Lipovljanski susreti '81, ur. Jovan Mirković (Lipovljani, 1981), 63; Marinko Gruić, „Romi: Neka aktualna pitanja socijalne emancipacije i nacionalne afirmacije“, u: Lipovljanski susreti '81, 26.

${ }^{73}$ Milan Bastašić, Bilogora i Grubišno Polje 1941-1991. (Banja Luka-Beograd, 2009), 103.

74 Šteković, Romi u virovitičkom kraju, 49-50.

75 Šteković, Romi u virovitičkom kraju, 49; Vladimir Dedijer, Dnevnik: 1941-1944: Od 28. novembra 1942. do 10. novembra 1943., knj. 2 (Rijeka, 1981), 469. 


\section{Spašavanje Roma u Slavoniji za vrijeme Nezavisne Države Hrvatske}

Dostupna znanstvena istraživanja sugeriraju kako je stanovništvo na hrvatskim područjima, slično kao i u većini drugih europskih zemalja, negativno percipiralo Rome, smatrajući ih lijenčinama (besposličarima), varalicama i kriminalcima. ${ }^{76}$ No, unatoč takvoj (,tradicionalnoj“) negativnoj percepciji, dio stanovništva NDH nastojao je - pojedinačno ili skupno - pomoći Romima koji su se našli na udaru ustaške represivne politike. Neromi su bili svjedocima ustaškog deportiranja Roma u logore, gdje je većina njih i ubijena. Kolone Roma, koje su vodili ustaše uz pomoć vojske i redarstvenika, zasigurno nisu mogle ostati neprimijećene široj javnosti. Tako se krajem svibnja 1942. prilikom prolaska kolone Roma ulicama Osijeka dogodilo da je jedna Osječanka pristupila Romkinji iz kolone te ju je javno zagrlila i poljubila. Takav iskaz emocija i određene empatije prema Romima nije se svidio osječkoj Njemici Matildi Beck, koja se zbog toga verbalno sukobila s Osječankom te ju desetak dana kasnije prijavila „,nadležnim“ njemačkim vlastima u istome gradu. ${ }^{77} \mathrm{U}$ tom kontekstu potrebno se osvrnuti i na sjećanja osoba koje su svjedočile deportacijama Roma. Primijetili su kako su ustaše nastojale deportirane Rome sasvim odvojiti od ikakvoga kontakta s drugim stanovništvom tijekom deportacija te su znale i nasilno kažnjavati Rome za bilo kakav kontakt s drugima. ${ }^{78}$ Kata Vagner, gostioničarka iz Bekteža (kotar Požega) poslala je 5. lipnja 1942. molbu kotarskim vlastima u Požegi u kojoj je tražila povratak iz jasenovačkog logora Roma Mije Jelenića, koji je kod nje radio dvije godine. Kao razloge za oslobođenje spomenutog Roma navodi da on „služi kod mene već dvije godine, a i prije toga služio je na području općine Bektež. - Napominjem da je isti pošten i radin dečko, odnosno u nekoliko primjera spriječio je kod mene gradju [krađu, op. a.] od lopova, kao i na drugim mjestima. Osim toga je poslušan marljiv i vrijedan, da i medju arijevcima imade vrlo malen broj takvih poštenjaka. - Kako je po naslovu a po naredjenju viših oblasti naredjeno hapšenje istoga, kao ciganina, u svrhu da se cigane prisili na rad i red, to držim da bi se istoga ostavilo kao časnu iznimku, jer je isto to dosadanjim svojim predživotom zaslužio. Još jednom dodajem i molim da se istoga ostave kod mene obzirom na poljske radove, a u oskudici sam sa nadničarima, i nemogu ih dobiti, te neću moći obraditi svoja polja i time doprinijeti državi obol u hrani, a obzirom što pomenutog nje potrebno prisiljavati na rad jer isti već nekoliko godina marljivo i na sveobće zadovoljstvo cijeloga se sela Bekteža

\footnotetext{
${ }^{76}$ Danijel Vojak, „Odnos između seoskog i romskog stanovništva na području Hrvatske i Slavonije, 1900.-1910.“, Sociologija sela: časopis za istraživanje prostornoga i sociokulturnog razvoja 42 (2004), 165-166 (3-4): 363-383.

${ }^{77}$ M.[ilan] Grozdanić, U ime Krista i Übermenscha (Osijek, 1958), 16-17.

${ }^{78}$ Dragoljub Acković, Ubili su istinu u nama (Beograd: Rrominterpress, 2001), 83.
} 
radi držim da bi isti ipak mogao ostati kao časna iznimka“. ${ }^{79}$ Navedenu molbu Kate Vagner poduprle su tamošnje vlasti Ustaškog tabora, koje su tražile oslobođenje Roma Mije Jelenića. Nije poznato jesu li nadležne ustaške vlasti usvojile ovu molbu i oslobodile spomenutog Roma iz jasenovačkog logora. Slično Kati Vagner, 53 stanovnika sela Kutjeva zatražilo je u lipnju 1942. od nadležnih požeških kotarskih vlasti povratak (oslobođenje) Roma Djure Jelenića iz jasenovačkog logora. U molbi je navedeno kako je Djuro dobar radnik, zajedno sa svojom obitelji, a pritom su istaknuli kako on nije skitnica, rimokatoličke je vjere i posjeduje vlastitu kuću. ${ }^{80}$ Ova molba je poslana 8. lipnja 1942., znači tri dana nakon deportacije Roma iz Kutjeva, na Zapovjedništvo sabirnog logora Jasenovac. Ono što je još potrebno istaknuti u ovom slučaju jest kako je Djurin sin Ivan Jelenić, tada kao domobran stacioniran u Osijeku, pred kotorskim vlastima u Požegi dao izjavu kojom je tražio puštanje njegove obitelji iz jasenovačkog logora. ${ }^{81}$ Sva navedena dokumentacija poslana je nadležnoj redarstvenoj oblasti u Novoj Gradišci, no ni u ovom slučaju nije poznat krajnji ishod.

U ovom kontekstu potrebno je navesti inicijativu općinskih vlasti iz Vrpolja (kotar Đakovo), koje su molbama, vjerojatno tamošnjeg stanovništva, naknadno spasile iz logora desetak Roma starosjedilaca i rimokatolika s njihova područja. ${ }^{82}$ No, nisu sve općinske vlasti mogle zaštititi Rome, o čemu nam govori primjer načelnika općine Valpovo iz sredine 1942., koji je zajedno sa svojim mještanima neuspješno pokušao od viših vlasti dobiti poštedu od deportacije u logor za četiri romske obitelji.$^{83} \mathrm{U}$ tom razdoblju zabilježena je inicijativa za spašavanje Roma od deportacija u logore kod seljaka iz Kutjeva. Naime, sredinom 1942. su, za vrijeme deportacija Roma s kutjevačkog područja, uhićena 44 Roma i predana ustašama u Slavonskoj Požegi, a njihova imovina predana je na „čuvanje“ općinskim vlastima, dok im je bilo dozvoljeno ponijeti samo najnužnije od odjeće i hrane. Tada je dio seljaka iz Kutjeva svojim potpisima neuspješno nastojao garantirati za sumještane Rome, ističući kako su oni mirni i radišni ljudi te kako bi ih se zbog toga trebalo izuzeti iz deportacija u logore. ${ }^{84}$ Dio stanovništva Dalja nastojao je spasiti tamošnje Rome od deportacije u jasenovački logor. Između ostalih svjedoka tom slučaju, Krešimir Vinaj je kao ustaški tabornik u Dalju opisao u srpnju 1951.

\footnotetext{
${ }^{79}$ DASB-PŽ-16, kut. 20, br. 10720/1942.

${ }^{80}$ DASB-PŽ-16, kut. 22, br. 12045/1942.

${ }^{81}$ Isto.

${ }^{82}$ Slavica Hrečkovski, Slavonski Brod u NOB i socijalističkoj revoluciji 1941 - 1945. (Slavonski Brod, 1982), 48; Hrečkovski, „Progoni i deportacije“, 36.

${ }^{83}$ Acković, Ubili su istinu, 59.

${ }^{84}$ Hrečkovski, „Progoni i deportacije“, 36; Milošević, Izbjeglice i preseljenici, 241; Dane Pavlica, Kronologija događaja u Požeškoj kotlini 1941. (Slavonska Požega, 1991), 33.
} 
kako je jedanaest romskih obitelji iz Dalja deportirano u jasenovački logor u lipnju 1942. Većinom se po njemu radilo o „poštenim i marljivim građanima“, zbog čega je odmah reagiralo tamošnje stanovništvo, tražeći od njega da vrati deportirane Rome. Vinaj je zatim neuspješno to pokušao ishoditi od Ivana Strlića, tamošnjeg općinskog bilježnika, koji je istaknuo kako nije u njegovoj nadležnosti to učiniti. Zatim je reagirao Josip Bago, kao općinski načelnik u Dalju, i telefonski je kontaktirao Katića (kotarskog predstojnika u Osijeku), koji je odbio reagirati u korist oslobađanja Roma, navevši kako se postupalo u skladu s odlukom ministarstva unutarnjih poslova NDH. ${ }^{85}$ Slično njemu, Kristo Glumčić je u iskazu iz kolovoza 1951. naveo kako je polovinom 1942. kao kotarski predstojnik Osijeka primio na sastanak Josipa Bagu (općinskog načelnika u Dalju) i Krešimira Vinaja (ustaškog tabornika u Dalju), koji su došli ,intervenirati“ u korist deportiranih Roma i tražiti njihovu ,slobodu“, jer su oni „dobri ljudi“. On im je negativno odgovorio, ističući kako su oni već odvedeni i to je bilo u skladu s „raspisom“ Andrije Artukovića kao ministara unutarnjih poslova. ${ }^{86}$ Iz ovih iskaza uočljivo je kako je među lokalnim vlastima i stanovništvom Dalja postojala zabrinutost za sudbinu deportiranih sumještana Roma, no istodobno su bili nemoćni u pokušaju njihovog spašavanja.

Navedeni slučajevi u kojima je neromsko stanovništvo, često u suradnji s lokalnim vlastima, pokušalo spasiti Rome od ustaškog progona i deportacija u logore ne mogu se ocijeniti kao organizirani oblik otpora stanovništva prema ustaškoj vlasti. Ovakvi pokušaji mogu se ponajprije tumačiti kao neposredan izraz (ljudskog) suosjećanja ne-romskog stanovništva prema progonjenim Romima.

\section{O razmjerima stradanja Roma iz Slavonije}

Pitanje brojčanog stradanja Roma u Drugom svjetskom ratu možda je najviše (kvantitativno), no ne i najbolje (kvalitativno) istraženo područje unutar onoga što im se događalo tijekom toga razdoblja. Romsko stanovništvo na području Nezavisne Države Hrvatske bilo je gotovo u potpunosti demografski uništeno, iako tim „službenim podacima“ uvijek treba pristupiti s velikim oprezom zbog metodoloških i drugih pitanja (poput etničke mimikrije Roma) ${ }^{87}$ Upravo zbog navedenoga, postoje značajne razlike među znanstvenicima u „procjenama“ broja ubijenih Roma u NDH, koje variraju od neko-

\footnotetext{
${ }^{85}$ HR-HDA-421, kut. 128, Krešimir Vinaj.

${ }^{86}$ HR-HDA-421, kut. 128, Kristo Glumčić.

${ }^{87}$ Franjo Tuđman, Bespuća povijesne zbiljnosti: Rasprava o povijesti i filozofiji zlosilja (Zagreb, 1989), 331; Jozo Tomasevich, Rat i revolucija u Jugoslaviji: okupacija i kolaboracija: 1941-1945. (Zagreb, 2010), 676-677.
} 
liko tisuća ubijenih pa do više od $100.000 .^{88}$ Potrebno je imati na umu kako su predratni popisi stanovništva zabilježili oko 15.000 Roma (1931.), a prvi poslijeratni popis stanovništva iz 1948. zabilježio ih je samo 405 na području Hrvatske i 442 na području Bosne i Hercegovine. Na slavonskom području je 1948. popisano samo 52 Roma, što znači da je predratna romska zajednica bila gotovo istrijebljena u Drugom svjetskom ratu. ${ }^{89}$

\section{Zaključak}

Romsko stanovništvo je u razdoblju do Drugoga svjetskog rata u znatnoj većini živjelo na hrvatskim područjima, i to posebno u Slavoniji. Njihov život na ovim područjima bio je obilježen razdobljima određenog suživota, no i onima koja se odnose na progone i asimilaciju. Takvo je bilo razdoblje Drugoga svjetskog rata, kada su ustaške vlasti i na ovim područjima Nezavisne Države Hrvatske provodile genocidnu politiku prema romskom stanovništvu. Istraživanje je pokazalo kako su Romi iz Slavonije bili žrtve takve genocidne politike, koja je započela donošenjem rasnih zakona krajem travnja 1941., kojima su Romi stavljeni izvan zakonske zaštite vlasti. Slijedilo je provođenje popisivanja Roma u ljeto iste godine, kako bi ustaške vlasti prikupile ključne demografsko-geografske podatke o njima. Na temelju tih podataka, započinje sredinom 1942. sustavna deportacija Roma iz svih dijelova NDH u jasenovački koncentracijski logor, što je bilo provedeno i na slavonskom području. Nakon deportacija, vlasti su preuzimale romsku imovinu, koju su zatim ili prodavale ili predavale određenim osobama. U samom jasenovačkom logoru, mnogi Romi s ovog područja bili su mučeni i ubijeni, a tek manji dio njih se uspio (bijegom) spasiti. Oni su svjedočili izravnoj politici ustaškog istrebljenja njihovih sunarodnjaka. Jedan dio Roma uspio se spasiti od ustaških deportacija i pristupiti antifašističkom pokretu. No, po završetku rata postali su vidljivi znatni demografski i drugi razmjeri stradanja romskog stanovništva. Brojna slavonska područja ostala su bez Roma, a time i bez dijela svoje povijesti.

\footnotetext{
${ }^{88}$ Vojak, „Zaboravljene žrtve“, 270-275.

${ }^{89}$ Konačni rezultati popisa stanovništva od 15 marta 1948 godine, Knjiga IX: Stanovništvo po narodnosti (Beograd, 1954), 348-393.
} 


\section{Summary \\ THE PERSECUTION OF THE ROMA POPULATION IN SLAVONIA DURING THE SECOND WORLD WAR (1941-1945)}

The Roma population had lived in a significant number in the Slavonian region, especially since the 18 th century when they inhabited deserted areas after the withdrawal of the Ottomans. Their life in Slavonia was mostly marked by periods of persecution and assimilation, as was the especially case in the second half of the 18th Century during the rule of the Mary Theresa and Joseph II. Such a repressive policy will have its peak during the Second World War with the coming of power of the Ustasa in the Independent State of Croatia. The Roma will be one of the main victims groups of the Ustasha racial politics. At the same time, almost $40 \%$ of Roma had lived in Slavonia during the Second World War, and they will be almost all deported to the Jasenovac concentration camp in mid-1942, where most of them had been tortured and killed. The proportions of such Ustasha policies will be particularly visible after the war, when only about fifty Roma were recorded in this area (1948).

Key words: Roma, Slavonia, Independent State of Croatia, Second World War, persecution

\section{Kontakt autora:}

Dr. sc. Danijel Vojak, viši znanstveni suradnik

Institut društvenih znanosti Ivo Pilar, Marulićev trg 19/1, 10000 Zagreb

e-mail: danijel.vojak@pilar.hr 
